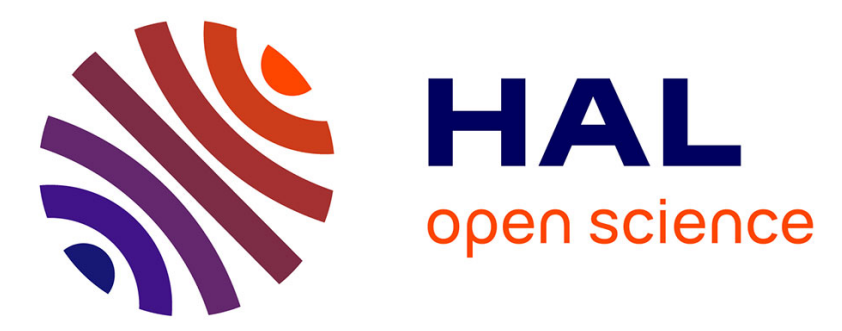

\title{
Impacts of environmental levels of hydrogen peroxide and oxyanions on the redox activity of $\mathrm{MnO} 2$ particles
}

Daqing Jia, Qinzhi Li, Tao Luo, Olivier Monfort, Gilles Mailhot, Marcello Brigante, Khalil Hanna

\section{- To cite this version:}

Daqing Jia, Qinzhi Li, Tao Luo, Olivier Monfort, Gilles Mailhot, et al.. Impacts of environmental levels of hydrogen peroxide and oxyanions on the redox activity of $\mathrm{MnO} 2$ particles. Environmental Science: Processes \& Impacts, 2021, 23 (9), pp.1351-1361. 10.1039/d1em00177a . hal-03331228

\author{
HAL Id: hal-03331228 \\ https://hal.science/hal-03331228
}

Submitted on 21 Sep 2021

HAL is a multi-disciplinary open access archive for the deposit and dissemination of scientific research documents, whether they are published or not. The documents may come from teaching and research institutions in France or abroad, or from public or private research centers.
L'archive ouverte pluridisciplinaire HAL, est destinée au dépôt et à la diffusion de documents scientifiques de niveau recherche, publiés ou non, émanant des établissements d'enseignement et de recherche français ou étrangers, des laboratoires publics ou privés. 


\section{Impacts of environmental levels of hydrogen peroxide and oxyanions on the redox activity of $\mathrm{MnO}_{2}$ particles}

Daqing Jia ${ }^{\mathrm{a}}$, Qinzhi Li ${ }^{\mathrm{b}}$, Tao Luo ${ }^{\mathrm{b}}$, Olivier Monfort ${ }^{\mathrm{d}}$, Gilles Mailhot ${ }^{\mathrm{a}}$, Marcello Brigante ${ }^{\mathrm{a}}$, Khalil Hanna ${ }^{\mathrm{b}, \mathrm{c}^{*}}$

${ }^{a}$ Université Clermont Auvergne, CNRS, Clermont Auvergne INP, Institut de Chimie de Clermont-Ferrand, F-63000 Clermont-Ferrand, France.

${ }^{b}$ Univ. Rennes, École Nationale Supérieure de Chimie de Rennes, CNRS, ISCR UMR 6226, F35000 Rennes, France

${ }^{c}$ Institut Universitaire de France (IUF), MESRI, 1 rue Descartes, 75231 Paris, France. ${ }^{d}$ Comenius University in Bratislava, Faculty of Natural Sciences, Department of Inorganic Chemistry, Ilkovicova 6, Mlynska Dolina, 84215 Bratislava, Slovakia.

*Corresponding author: +33223238027, khalil.hanna@ensc-rennes.fr 


\begin{abstract}
Despite the widespread presence of hydrogen peroxide in surface water and groundwater systems, little is known about the impact of environmental levels of $\mathrm{H}_{2} \mathrm{O}_{2}$ on the redox activity of minerals. Here we demonstrate that environmental concentrations of $\mathrm{H}_{2} \mathrm{O}_{2}$ can alter the reactivity of birnessite-type manganese oxide, an earth-abundant functional material, and decrease its oxidative activity in natural systems across a wide range of $\mathrm{pH}$ values (4-8). The $\mathrm{H}_{2} \mathrm{O}_{2}$-induced reductive dissolution generates $\mathrm{Mn}(\mathrm{II})$ that will re-bind to $\mathrm{MnO}_{2}$ surfaces, thereby affecting the surface charge of $\mathrm{MnO}_{2}$. Competition of Bisphenol $\mathrm{A}$ (BPA), used as a target compound here, and $\mathrm{Mn}(\mathrm{II})$ to interact with reactive surface sites may cause suppression of the oxidative ability of $\mathrm{MnO}_{2}$. This suppressive effect becomes more effective in presence of oxyanions such as phosphate or silicate at concentrations comparable to those encountered in natural waters. Unlike nitrate, adsorption of phosphate or silicate onto birnessite increased in presence of $\mathrm{Mn}(\mathrm{II})$ added or generated through $\mathrm{H}_{2} \mathrm{O}_{2}$-induced reduction of $\mathrm{MnO}_{2}$. This suggests that naturally occurring anions and $\mathrm{H}_{2} \mathrm{O}_{2}$ may have synergetic effects on the reactivity of birnessite-type manganese oxide at a range of environmentally relevant $\mathrm{H}_{2} \mathrm{O}_{2}$ amounts. As layered structure manganese oxides play a key role in the global carbon cycle as well as pollutant dynamics, the impact of environmental levels of hydrogen peroxide $\left(\mathrm{H}_{2} \mathrm{O}_{2} / \mathrm{MnO}_{2}\right.$ molar ratio $\leq 0.3$ ) should be considered in environmental fate and transport models.
\end{abstract}

Keywords: birnessite; redox; hydrogen peroxide; oxyanion. 


\section{Table of contents}

$\mathrm{H}_{2} \mathrm{O}_{2} / \mathrm{MnO}_{2}$ molar ratio as low as 0.03 can affect the redox activity of $\mathrm{MnO}_{2}$ particles and their reactivity in natural systems.
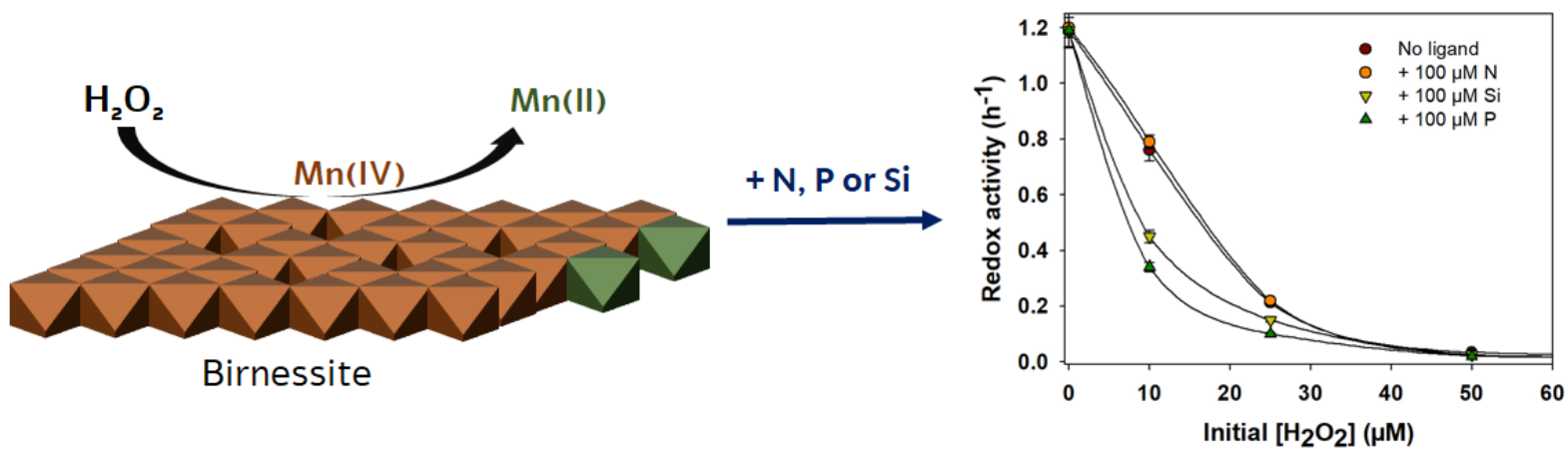


\section{Introduction}

Layered structure manganese oxides (e.g. birnessite) are ubiquitous in a wide range of aquatic and terrestrial environments. ${ }^{1}$ The presence of exchangeable hydrated cations within the interlayers combined with a high content of vacancy sites and variable oxidation states of manganese make them powerful sorbents and oxidants., ${ }^{2,3}$ As a result, birnessite-type manganese oxides play a significant role in controlling the cycles of several key nutrients as well as the fate and mobility of inorganic and organic contaminants. ${ }^{4-9}$ Acid birnessite has been widely investigated because it is structurally similar to biogenic "natural" manganese oxides. ${ }^{10-}$ 13 The birnessite reactivity is mainly affected by solution $\mathrm{pH}$, surface properties and composition of $\mathrm{MnO}_{2}$ and structural characteristics of redox-active contaminants. ${ }^{4-6,12}$ It can also be influenced by the presence of naturally occurring compounds, e.g. cations, anions, natural organic matter and other redox-active compounds. Among the latter, hydrogen peroxide $\left(\mathrm{H}_{2} \mathrm{O}_{2}\right)$ has an ambivalent redox activity and is commonly found in aquatic environments at concentration ranging from $\mathrm{nM}$ to $\mu \mathrm{M} .^{14-26}$

In environmental systems, photodependent reactions mediated by natural organic matter and biological-mediated processes dominate $\mathrm{H}_{2} \mathrm{O}_{2}$ production. ${ }^{26}$ Sunlight-induced photochemical reactions mediated by organic ligands and/or biochemical metabolic processes can result in amounts of $\mathrm{H}_{2} \mathrm{O}_{2}$ up to $20 \mu \mathrm{M} \cdot{ }^{14-18}$ Input from rainwater can reach up to $40 \mu \mathrm{M}$ ${ }^{20,21}$, while hydrogen peroxide production has been often observed in irradiated seawater. ${ }^{19-21}$ Light-independent generation of $\mathrm{H}_{2} \mathrm{O}_{2}$ has been recently reported in river sediments and in groundwater of an alluvial aquifer, which is likely to occur in transitional redox environments where reduced elements react with oxygen. ${ }^{22,23}$ For example, natural hydroquinones or hydroquinone moieties ubiquitously present in reduced organic matter can donate electrons to

$\mathrm{O}_{2}$ to generate $\mathrm{H}_{2} \mathrm{O}_{2}{ }^{24,25} \mathrm{H}_{2} \mathrm{O}_{2}$ production through microbial mechanism has also been shown to enhance iodide oxidation and organo-iodine formation in soils and sediments. ${ }^{27}$ All these 
studies suggested that $\mathrm{H}_{2} \mathrm{O}_{2}$ can be formed not only in oceanic and atmospheric systems but also in the subsurface environment. Finally, higher concentrations (up to $1 \mathrm{mM}$ ) have been reported in nuclear waste repository scenarios when ionizing radiation of groundwater adjacent to spent nuclear fuel result in $\mathrm{H}_{2} \mathrm{O}_{2}$ production. ${ }^{28}$

Despite the catalyzed decomposition of hydrogen peroxide by $\mathrm{MnO}_{2}$ has been well investigated ${ }^{29-31}$, knowledge is very limited on the effect of $\mathrm{H}_{2} \mathrm{O}_{2}$ on the reactivity of birnessite at environmental levels of $\mathrm{H}_{2} \mathrm{O}_{2}$. In engineering applications, metal oxides such as $\mathrm{MnO}_{2}$ are generally investigated for catalytic decomposition of $\mathrm{H}_{2} \mathrm{O}_{2}$ and then formation of reactive transient species using very high concentrations of hydrogen peroxide $\left(\mathrm{H}_{2} \mathrm{O}_{2}\right)(\geq 0.5 \mathrm{mM}){ }^{29-31}$ While these remediation studies aimed to eliminate pollution in contaminated systems, they overlooked the influence of $\mathrm{H}_{2} \mathrm{O}_{2}$ on the electron transfer heterogeneous reaction and then the oxidative activity of birnessite. In addition, little is known about the influence of $\mathrm{H}_{2} \mathrm{O}_{2}$ on the birnessite composition and interactions of redox products (e.g. $\mathrm{Mn}(\mathrm{II}))$ with $\mathrm{MnO}_{2}$ surfaces.

In this study, we examine how $\mathrm{H}_{2} \mathrm{O}_{2}$ affects the reactivity of birnessite under environmentally relevant conditions. To monitor $\mathrm{H}_{2} \mathrm{O}_{2}$-induced changes in birnessite reactivity, we used Bisphenol A (BPA) as a model compound because it has a strong reactivity with the birnessite $\left(\delta-\mathrm{MnO}_{2}\right)$, with a well-documented underlying redox mechanism. ${ }^{32-35}$ Acid birnessite, a well-established laboratory synthesized analog of layered birnessite mineral, was chosen as a representative manganese dioxide mineral. The removal kinetics of BPA have been assessed in presence of variable amounts of $\mathrm{H}_{2} \mathrm{O}_{2}$ under a wide range of $\mathrm{pH}(4,6.5$ and 8) under aerobic and anaerobic conditions. Alteration of birnessite structure and composition was monitored using XRD and titration experiments under different conditions $\left(\mathrm{H}_{2} \mathrm{O}_{2} / \mathrm{MnO}_{2}\right.$ molar ratio, dissolved $\mathrm{Mn}(\mathrm{II})$ amount and $\mathrm{pH}$ value). To check whether the impact of $\mathrm{H}_{2} \mathrm{O}_{2}$ can persist in natural waters, changes in birnessite reactivity were investigated in presence of commonly found anionic ligands such as phosphate, nitrate and silicate. We notably demonstrated that at 
$\mathrm{H}_{2} \mathrm{O}_{2}$ concentrations as low as $10 \mu \mathrm{M}$ or with $\mathrm{H}_{2} \mathrm{O}_{2} / \mathrm{MnO}_{2}$ molar ratio as low as 0.03 , the reactivity of acid birnessite can be affected, which could alter biogeochemical cycles as well as pollutant dynamics.

\section{Materials and Methods}

\subsection{Chemicals}

$\mathrm{KMnO}_{4}, \mathrm{HCl}, \mathrm{NaCl}, \mathrm{NaOH}, \mathrm{HEPES}, \mathrm{H}_{2} \mathrm{C}_{2} \mathrm{O}_{4}, \mathrm{H}_{2} \mathrm{SO}_{4}$, hydroxylamine hydrochloride, $\mathrm{H}_{2} \mathrm{O}_{2}$, BPA, $\mathrm{HNO}_{3}$, terephthalic acid, 2-hydroxyterephthalic acid, $\mathrm{Na}_{2} \mathrm{SiO}_{3}, \mathrm{NaNO}_{3}, \mathrm{NaH}_{2} \mathrm{PO}_{4}$ and $\mathrm{MnCl}_{2}$ were purchased from Sigma-Aldrich and were all AR grade. All chemicals were used as received without further purification. All solutions were prepared in ultrapure water obtained from a water purification system (Millipore, resistivity $18.2 \mathrm{M} \Omega \mathrm{cm}$ ).

\subsection{Synthesis and characterization of acid birnessite}

Acid birnessite was prepared following the procedure of $\mathrm{McKenzie}^{36}$, and Mn(III)-rich $\mathrm{MnO}_{2}$ was synthesized according to previous published methods. ${ }^{37,38}$ More details are provided in the Supporting Information (SI). The solid was characterized using X-ray powder diffraction (XRD) using the Bruker AXS D8 Advance diffractometer ( $\theta-2 \theta$ Bragg-Brentano geometry) using monochromatized $\mathrm{CuK \alpha} 1(1.54 \AA)$ radiation over the range of $10^{\circ}-100^{\circ} 2 \theta$ at a step size of $0.02^{\circ}$. X-ray diffraction (XRD) confirmed that the only product of the synthesis was poorlycrystalline hexagonal birnessite. The Brunauer-Emmett-Teller (BET) specific surface area of the synthetic birnessite measured by multipoint $\mathrm{N}_{2}$ adsorption was $60 \pm 2.5$ (SD) $\mathrm{m}^{2} \mathrm{~g}^{-1}$. The Average Oxidation State $(\mathrm{AOS}=3.98( \pm 0.02))$ of synthetic birnessite and $(\mathrm{AOS}=3.65( \pm 0.02))$ of $\mathrm{Mn}(\mathrm{III})$-rich $\mathrm{MnO}_{2}$ were measured using the oxalic acid-permanganate back-titration method (more details are provided in SI). Scanning Electron Microscope (SEM; JEOL JSM-7100F) and 
High-resolution Transmission Electron Microscope (HRTEM; JEOL 2100 LaB6) images showed a nanoflower-shaped birnessite consisting of nanoflakes aggregations (see Figure S1).

\subsection{Kinetics experiments and analyses}

Reactivity changes assessment were investigated as following: $100 \mathrm{~mL}$ aqueous suspension of acid birnessite $(\mathrm{AB})$ corresponding to an initial concentration of $345 \mu \mathrm{M}$ was first prepared and then an appropriate amount of stock solutions of $\mathrm{H}_{2} \mathrm{O}_{2}, \mathrm{BPA}$, and/or $\mathrm{Mn}$ (II) were added to start the reaction at room temperature. Since the involved reactions can consume protons (see below), the $\mathrm{pH}$ was adjusted to the desired value and then kept constant throughout the reaction using a $\mathrm{pH}$ meter (Cyberscan 510, Thermo Scientific) by adding $0.1 \mathrm{M} \mathrm{NaOH}$ or HCl. The suspension was stirred with a speed of $350 \mathrm{rpm} .1 \mathrm{~mL}$ of aqueous sample was withdrawn at different time interval, filtered through $0.22 \mu \mathrm{m}$ PTFE filter, and then analyzed. The same batch experiments were carried out in the presence of silicate or phosphate to evaluate the combined effects of anions and $\mathrm{H}_{2} \mathrm{O}_{2}$ on BPA oxidation.

Potential generation of hydroxyl radical was monitored through the fluorescence emission spectrum of 2-hydroxyterephthalic acid $\left(\lambda_{\mathrm{ex}} 320 \mathrm{~nm}, \lambda_{\mathrm{em}} 425 \mathrm{~nm}\right)$ using a spectrofluorometer (Shimadzu RF-5301PC) (more information is given in the SI).

The BPA concentration was determined by a high-performance liquid chromatography system (HPLC, Waters Alliance) equipped with a diode array detector (DAD). Chromatographic separation was performed using a Nucleodur $100-5$ C18 column $(150 \times 4.6$ $\mathrm{mm}, 5 \mu \mathrm{m}$ of particle size, Macherey Nagel). The detection wavelength of BPA was set at 277 $\mathrm{nm}$ and the column temperature was kept at $30^{\circ} \mathrm{C}$. Methanol and water were mixed as the mobile phase under a gradient eluent mode, and the percentage of methanol changed with time was as follows: from 0 to 7 min was increased from 70 to $90 \%$ and kept constant up to 9 min.

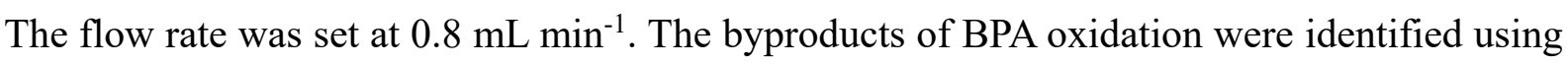
Ultraperformance Liquid Chromatography-tandem Mass Spectrometry (UPLC-MS/MS) 
system. An electrospray interface was used for the MS measurements in positive ionisation mode and full scan acquisition.

$\mathrm{H}_{2} \mathrm{O}_{2}$ concentration was determined using a spectrofluorometric detection as described in our previous work. ${ }^{39}$ Briefly, samples containing $\mathrm{H}_{2} \mathrm{O}_{2}$ were mixed with 4-hydroxyphenylacetic acid to form the stable 4-hydroxyphenyl acetic acid dimer in the presence of peroxidase (POD, Sigma-Aldrich). The 4-hydroxyphenylacetic acid dimer was quantified using a Cary Eclipse fluorescence spectrophotometer. The excitation wavelength was set at $320 \mathrm{~nm}$ and emission wavelength maximum was determined at $420 \mathrm{~nm}$. Concentration was calculated using calibration curve obtained using different concentrations of $\mathrm{H}_{2} \mathrm{O}_{2} .{ }^{40}$

Dissolved Mn(II) concentration in aqueous solution was determined by Atomic Absorption Spectroscopy (AAS, PerkinElmer). All the samples were first filtered using a PTFE $0.22 \mu \mathrm{m}$ filter and then mixed with $2 \%$ nitric acid $\left(\mathrm{HNO}_{3}, 65 \%\right.$, Sigma- Aldrich) prior for analyses. Dissolved Mn(II) standard solution for AAS (TraceCERT®, $1000 \mathrm{mg} \mathrm{L}^{-1} \mathrm{Mn}$ (II) in $2 \%$ nitric acid, Sigma-Aldrich) was used for the calibration curve. The detection wavelength was set at $279 \mathrm{~nm}$ and the AAS detection limit lied at $0.02 \mu \mathrm{M}$. Mn(II) removal was calculated as the difference between the initial and final Mn(II) solution concentrations.

The impact of anions on reactivity changes was investigated as mentioned above, but with addition of the chosen anion with BPA or Mn(II) to the AB suspension. Silicate concentration was determined by the molybdenum-blue colorimetric method ${ }^{41}$ while phosphate and nitrate concentrations by ion chromatography. ${ }^{42} \mathrm{XRD}$ was performed to determine the possible transformation of solids upon $\mathrm{Mn}(\mathrm{II})$ sorption.

Since $\mathrm{Mn}(\mathrm{II})$ oxidation by molecular oxygen may take place, particularly at alkaline $\mathrm{pH}$ values, we compared the removal kinetics under aerobic (open atmosphere) vs anaerobic conditions (glove box $\mathrm{N}_{2}: \mathrm{H}_{2}$ 98:2). Prior for anoxic experiments, all solutions were sparged with nitrogen to remove oxygen. These preliminary tests showed that there is no effect of oxic 
conditions on the BPA removal in presence of $\mathrm{H}_{2} \mathrm{O}_{2}$ or $\mathrm{Mn}(\mathrm{II})$. Great attention has also been paid to the $\mathrm{pH}$ adjustment in all experiments, since the involved reactions are sensitive to $\mathrm{pH}$ value (see below). All experiments were conducted in triplicates and the standard deviation was calculated for all experimental series, and given in the caption of each figure.

\section{Results and Discussion}

\subsection{Effect of $\mathrm{H}_{2} \mathrm{O}_{2}$ on the oxidative ability of birnessite}

BPA removal was monitored in the presence of acid birnessite (AB) at different $\mathrm{H}_{2} \mathrm{O}_{2}$ concentrations at $\mathrm{pH} 6.5$ (Fig. 1). In the absence of $\mathrm{H}_{2} \mathrm{O}_{2}$, almost complete removal of BPA was observed after $24 \mathrm{~h}$ of reaction time. Mass balance showed that the oxidation reaction was mainly involved in the removal of BPA in presence of $\mathrm{MnO}_{2}$, while adsorption was very low under our experimental conditions (i.e. less than 5\% of initial BPA), which is consistent with previous investigations. ${ }^{6,32,33}$ Indeed, BPA containing two hydroxyphenyl functionalities is known to weakly interact with mineral surfaces, resulting in lower adsorption affinity to metal-

oxides. ${ }^{32}$ As previously reported, ${ }^{6,33,43}$ binding to birnessite is followed by an electron transfer process resulting in the concomitant oxidation of sorbed compound and reduction of surfacebound $\mathrm{Mn}(\mathrm{IV})$ to yield $\mathrm{Mn}(\mathrm{III})$ that can be further reduced to give $\mathrm{Mn}(\mathrm{II})$.

$$
\mathrm{Mn}^{\mathrm{IV}} \mathrm{O}_{2}+\mathrm{BPA}+4 \mathrm{H}^{+} \rightarrow \mathrm{Mn}^{\mathrm{II}}+\mathrm{BPA}_{\mathrm{ox}}+2 \mathrm{H}_{2} \mathrm{O}
$$

Electron exchange of BPA with $\mathrm{MnO}_{2}$ form a radical, followed by a series of reactions including radical coupling, fragmentation, substitution and elimination to form multiple byproducts. ${ }^{6,32,33} \mathrm{LC} / \mathrm{MS}$ analysis identified one predominant species of mass-to-charge ratio of $\mathrm{m} / \mathrm{z}=135$ as the most dominant byproduct of BPA over the first reaction time (90 min), which likely corresponds to 4-hydroxycumyl alcohol according to previous investigations. ${ }^{44}$

In the presence of hydrogen peroxide, the oxidative removal of BPA gradually decreased with increasing in $\mathrm{H}_{2} \mathrm{O}_{2}$ concentration, and completely suppressed at higher dose of $\mathrm{H}_{2} \mathrm{O}_{2}(200$ 
$\mu \mathrm{M}$ equivalent to a $\mathrm{H}_{2} \mathrm{O}_{2} / \mathrm{MnO}_{2}$ molar ratio 0.6). In these experiments, the $\mathrm{H}_{2} \mathrm{O}_{2}$ decomposition is relatively fast whatever the investigated $\mathrm{pH}$, since complete decomposition of $\mathrm{H}_{2} \mathrm{O}_{2}$ was achieved after 15 min of reaction, even for the highest $\mathrm{H}_{2} \mathrm{O}_{2}$ dose (See Fig. S2 and S3). Monitoring of fluorescence emission spectra of suspensions using a terephthalate as a chemical probe indicated that no hydroxyl radical was generated under the experimental conditions of this study. Additional experiments using 1-propanol (1 mM) or t-butanol (1 mM) as hydroxyl-radical scavengers confirmed that the BPA removal is a no radical-based oxidation process regardless of the presence or absence of $\mathrm{H}_{2} \mathrm{O}_{2}$.

The suppressive effect of $\mathrm{H}_{2} \mathrm{O}_{2}$ on the removal rate of BPA was then confirmed at two other $\mathrm{pH}$ values (4 and 8 ). The removal kinetics could not be properly described by simple equations that include classical exponential functions (e.g., first- or second- order model), probably due to the complexity of involved reactions in the investigated system. Instead, we calculated the initial rate constant $\left(k, \mathrm{~h}^{-1}\right)$ by linear regression of $\ln [\mathrm{BPA}] /[\mathrm{BPA}]_{\mathrm{o}}$ versus time over the first stage of reaction (see example in Fig. S4). The initial rate constants for all investigated $\mathrm{H}_{2} \mathrm{O}_{2}$ amounts exhibited the same order, $\mathrm{pH} 4>\mathrm{pH} 6.5>\mathrm{pH} 8$ (Fig. 2). In the absence of $\mathrm{H}_{2} \mathrm{O}_{2}, k$ was decreased almost 20 -fold when $\mathrm{pH}$ increased from 4 to 8 . This suggests that acidic conditions favored BPA removal, a trend also observed for other organic compounds reacting with $\mathrm{MnO}_{2}$. $33,34,45$ We attribute this to variability in two $\mathrm{pH}$-dependent factors: 1) speciation of BPA that affects binding to $\mathrm{MnO}_{2}$ surfaces and then oxidation (Fig. S5), and 2) redox-potential of $\mathrm{MnO}_{2}$ that decreases when the $\mathrm{pH}$ increased from 4 to $8 .{ }^{46}$ At relatively low $\mathrm{pH}$, favorable electrostatic interactions between neutral BPA molecules and the negatively charged surface of $\mathrm{MnO}_{2}(\mathrm{PZC}$ of $\mathrm{MnO}_{2}$ is $\sim 2.3-2.9$ ) may exist. On the other hand, reductive conversion of $\mathrm{MnO}_{2}$ into $\mathrm{Mn}(\mathrm{II})$ is dependent on the amount of protons, which would result in increase in BPA removal rate when the $\mathrm{pH}$ decreases (Eq.1). In the presence of $\mathrm{H}_{2} \mathrm{O}_{2}$, the removal rate constants of BPA sharply decreased with increasing in $\mathrm{H}_{2} \mathrm{O}_{2}$ amount whatever the investigated $\mathrm{pH}$ value (Fig. 2). 
As for BPA, it is previously reported that hydrogen peroxide can also reduce $\mathrm{Mn}(\mathrm{IV})$ to $\mathrm{Mn}(\mathrm{III})$ and then $\mathrm{Mn}(\mathrm{II})$ as follows ${ }^{47,48}$ :

$$
\mathrm{Mn}^{\mathrm{IV}} \mathrm{O}_{2}+\mathrm{H}_{2} \mathrm{O}_{2}+2 \mathrm{H}^{+} \rightarrow \mathrm{Mn}^{\mathrm{II}}+\mathrm{O}_{2}+2 \mathrm{H}_{2} \mathrm{O}
$$

To check this possibility under our experimental conditions, the reductive dissolution of $\mathrm{MnO}_{2}$ in presence of various amounts of $\mathrm{H}_{2} \mathrm{O}_{2}$ was monitored at three $\mathrm{pH}$ values (Fig. 3). In both Eq. 1 and Eq.2, protons are directly involved in the oxidation of BPA as well as the reductive dissolution of $\mathrm{MnO}_{2}$. In the absence of $\mathrm{H}_{2} \mathrm{O}_{2}$, dissolved $\mathrm{Mn}(\mathrm{II})$ was only detected at $\mathrm{pH} 4$, while it was below the detection limit at $\mathrm{pH} 6.5$ or 8 . Increasing $\mathrm{H}_{2} \mathrm{O}_{2}$ concentration from $50 \mu \mathrm{M}$ to $200 \mu \mathrm{M}$ enhanced the amount of dissolved Mn(II), at the three investigated $\mathrm{pH}$ values. At each $\mathrm{pH}$ value, the amount of dissolved $\mathrm{Mn}(\mathrm{II})$ increased first, reached a maximum and then decreased. This two-step behavior is consistent with the $\mathrm{H}_{2} \mathrm{O}_{2}$ decomposition over time, where the complete decomposition of $\mathrm{H}_{2} \mathrm{O}_{2}$ observed after approximately 15 min of reaction time coincides with the peak observed for dissolved Mn(II) generation (Fig. S3). This behavior also suggests that the production of $\mathrm{Mn}(\mathrm{II})$ via $\mathrm{H}_{2} \mathrm{O}_{2}$-induced reduction of $\mathrm{MnO}_{2}$ is faster than the $\mathrm{Mn}(\mathrm{II})$ adsorption onto birnessite. Once the added $\mathrm{H}_{2} \mathrm{O}_{2}$ is fully decomposed, the generated dissolved $\mathrm{Mn}(\mathrm{II})$ will in turn sorb onto $\mathrm{MnO}_{2}$ surfaces.

Because higher $\mathrm{pH}$ implies more $\mathrm{Mn}(\mathrm{II})$ binding $^{49-51}$, greater amounts of $\mathrm{Mn}(\mathrm{II})$ were observed at low $\mathrm{pH}$ values (Fig. 3). When a further addition of $\mathrm{H}_{2} \mathrm{O}_{2}$ is made after total decomposition of the initial amount (e.g. after $15 \mathrm{~min}$ at $\mathrm{pH}$ 4), the amount of generated $\mathrm{Mn}(\mathrm{II})$ increased again and reached almost twice the first measured amount within approximately $15 \mathrm{~min}$. This suggests that the reductive dissolution of $\mathrm{MnO}_{2}$ by $\mathrm{H}_{2} \mathrm{O}_{2}$ is a fast process, as compared to the reaction between $\mathrm{MnO}_{2}$ and BPA.

To check whether Eq.1 and Eq.2 may occur simultaneously during the heterogeneous reactions with $\mathrm{MnO}_{2}$, we compare the standard potential of involved reactions at the working 
$\mathrm{pH}$ range. $\mathrm{MnO}_{2}$ has standard (reduction) potential varying from 0.99 to $0.76 \mathrm{~V}$ when the $\mathrm{pH}$ rises from 4 to 8 for $\mathrm{MnO}_{2}+4 \mathrm{H}^{+}+2 \mathrm{e}^{-} \rightarrow \mathrm{Mn}^{\mathrm{II}}+2 \mathrm{H}_{2} \mathrm{O}$. This value is higher than the standard oxidation potential of $\mathrm{O}_{2} / \mathrm{H}_{2} \mathrm{O}_{2}\left(\mathrm{O}_{2}+2 \mathrm{H}^{+}+2 \mathrm{e}^{-} \rightarrow \mathrm{H}_{2} \mathrm{O}_{2}\right.$ 0.68 V vs. NHE) or of BPA which varies between $0.75 \mathrm{~V}$ and $0.52 \mathrm{~V}$ in the $\mathrm{pH}$ range $4-8 .{ }^{52-54}$ Since the latter redox couples have comparable oxidation potential, reactions (Eq.1) and (Eq.2) could simultaneously take place. Assuming that these reactions obey pseudo-first order kinetic equation because $\mathrm{MnO}_{2}$ is considered in excess, the reaction rate depends on the concentration of reactants (i.e. $\mathrm{H}_{2} \mathrm{O}_{2}$ or BPA). When the $\mathrm{H}_{2} \mathrm{O}_{2}$ amount increases, the reaction 2 should become much faster than the reaction 1. This was experimentally shown in Figures 1 and 3 and Figure S2, where both reactions Eq. 1 and Eq. 2 occurred simultaneously until complete inhibition of Eq. 1 at the highest $\mathrm{H}_{2} \mathrm{O}_{2}$ amount $(200 \mu \mathrm{M})$. Though $\mathrm{H}_{2} \mathrm{O}_{2}$ was full decomposed after 15 min of reaction time (Fig. S2), the suppressive effect on the birnessite reactivity was still observed over $24 \mathrm{~h}$ of reaction time (Fig. 1). This was confirmed by carrying out sequentially the reactions (Eq.2) and (Eq.1). Indeed, suppression of BPA removal capacity was also observed when $\mathrm{MnO}_{2}$ and $\mathrm{H}_{2} \mathrm{O}_{2}$ were allowed to react first (i.e. pre-equilibration step of $30 \mathrm{~min}$ ) until total decomposition of $\mathrm{H}_{2} \mathrm{O}_{2}$ before addition of BPA (Fig. S6). Therefore, the $\mathrm{H}_{2} \mathrm{O}_{2}$-mediated reduction of $\mathrm{MnO}_{2}$ (Eq.2) considerably affects the surface reactivity of birnessite and its ability to remove BPA. This reductive dissolution generates $\mathrm{Mn}(\mathrm{II})$ ions which will in turn bind to $\mathrm{MnO}_{2}$ surfaces and then be oxidized into higher valence Mn:

$$
\mathrm{Mn}^{\mathrm{II}}+\mathrm{MnO}_{2} \rightarrow \mathrm{Mn}^{\mathrm{II}} / \mathrm{Mn}^{\mathrm{III}}-\mathrm{MnO}_{2}
$$

This oxidation reaction may be made possible by the residual $\mathrm{H}_{2} \mathrm{O}_{2}$ and/or generated $\mathrm{O}_{2}$ (through Eq.2), which is $\mathrm{pH}$-dependent. The contribution of $\mathrm{O}_{2}$ from ambient air is excluded since reactivity assessment tests investigated under aerobic $v s$ anaerobic conditions showed similar behavior in term of BPA removal.

It is worth noting that strong aggregation of $\mathrm{MnO}_{2}$ particles and then fast sedimentation was 
observed upon addition of $\mathrm{H}_{2} \mathrm{O}_{2}$. This phenomenon can be ascribed to charge neutralization (i.e. surface charge switch from negative to positive) upon $\mathrm{Mn}$ (II) ions binding to negatively charged $\mathrm{MnO}_{2}$ surfaces, as previously reported. ${ }^{55}$ Furthermore, disproportionation/comproportionation reaction (Eq.4) may occur within the $\mathrm{MnO}_{2}$, i.e. $\mathrm{Mn}^{\mathrm{II}}$ exchanges electrons with $\mathrm{Mn}(\mathrm{IV}$ ) to form two $\mathrm{Mn}(\mathrm{III})$ centers and, conversely, two $\mathrm{Mn}$ (III) centers can disproportionate to form $\mathrm{Mn}(\mathrm{II})$ and $\mathrm{Mn}(\mathrm{IV})$ centers ${ }^{12,32,35,51,56}$ :

$$
\mathrm{Mn}^{\mathrm{II}}+\mathrm{Mn}^{\mathrm{IV}} \leftrightarrow 2 \mathrm{Mn}^{\mathrm{III}}
$$

Since this reaction is $\mathrm{pH}-\mathrm{dependent,} \mathrm{we} \mathrm{have} \mathrm{measured} \mathrm{the} \mathrm{average} \mathrm{oxidation} \mathrm{state} \mathrm{(AOS)}$ of birnessite over the whole investigated $\mathrm{pH}$ range (4-8). The AOS of samples reacted with BPA $(25 \mu \mathrm{M})$ alone only slightly decreased from 3.98 to $3.90( \pm 0.02)$. However, partial reduction of $\mathrm{MnO}_{2}$ upon addition of $200 \mu \mathrm{M}$ of $\mathrm{H}_{2} \mathrm{O}_{2}$ dropped down the AOS to $3.74( \pm 0.04)$ at $\mathrm{pH} 4$ and 6.5, and $3.61( \pm 0.04)$ at $\mathrm{pH}$ 8. This decrease suggests that percentages of $\mathrm{Mn}(\mathrm{III})$ or $\mathrm{Mn}(\mathrm{II})$ or both are relatively higher at the end of reaction with respect to the initial sample. The formation of $\mathrm{Mn}(\mathrm{III})$ was further confirmed by the detection of $\mathrm{Mn}(\mathrm{III})$-pyrophosphate complex at 480 $\mathrm{nm}, \mathrm{Mn}(\mathrm{III})$ being stabilized through ligand-binding complexes. ${ }^{57}$ The effect of $\mathrm{H}_{2} \mathrm{O}_{2}$ on the structure of birnessite will be discussed in the following section.

Collectively, these results suggest that the $\mathrm{H}_{2} \mathrm{O}_{2}$ induced reduction of $\mathrm{MnO}_{2}$ is an effective process, and the fast generation of $\mathrm{Mn}(\mathrm{II})$ is key for suppressed oxidative capacity of $\mathrm{MnO}_{2}$ towards BPA. To confirm the impact of $\mathrm{Mn}(\mathrm{II})$ on the reactivity of $\mathrm{MnO}_{2}$, BPA removal kinetics were investigated in $\mathrm{Mn}(\mathrm{II})$-amended birnessite suspensions in the following section.

\subsection{Effects of $\mathrm{Mn}(\mathrm{II})$ on the removal capacity of $\mathrm{MnO}_{2}$}

The initial rate constants of BPA removal sharply decreased with increasing in dissolved $\mathrm{Mn}(\mathrm{II})$ amount at $\mathrm{pH} 4$ and 6.5 , while at $\mathrm{pH} 8$ it increased first between 0 and $10 \mu \mathrm{M}$ but later decreased with increasing in initial Mn(II) amount (Fig. 5). It is previously reported that the 
adsorption of cations such as $\mathrm{Ca}(\mathrm{II})$ or $\mathrm{Mg}$ (II) may change the surface charge from negative to positive by exchange of $\mathrm{H}^{+}$on the $\mathrm{MnO}_{2}$ surface. ${ }^{58,59}$ Similarly, the $\mathrm{Mn}(\mathrm{II})$ adsorption should lead to a decrease in the negative surface charge, thereby altering the binding capacity of $\mathrm{MnO}_{2}$. When the Mn(II) amount further increases, we speculate a competition between BPA and Mn(II) to bind at reactive sites of $\mathrm{MnO}_{2}$ during the first kinetic phase, as recently observed for quinolones. $^{43}$

As for $\mathrm{H}_{2} \mathrm{O}_{2}$, dissolved $\mathrm{Mn}$ (II) displayed suppressive effects on the removal rate of BPA and the rate constants over the whole $\mathrm{Mn}(\mathrm{II})$ concentration range $(10-100 \mu \mathrm{M})$ exhibited the same order, $\mathrm{pH} 4>\mathrm{pH} 6.5>\mathrm{pH} 8$ (Fig. 5). In addition to the comproportionation reaction that is $\mathrm{pH}$ dependent, the decrease in the oxidative ability of $\mathrm{MnO}_{2}$ in the presence of dissolved $\mathrm{Mn}(\mathrm{II})$ may result from competition of compound and $\mathrm{Mn}(\mathrm{II})$ to interact with reactive surface sites. The strong binding of $\mathrm{Mn}(\mathrm{II})$ to $\mathrm{MnO}_{2}$ surfaces suggests competition of $\mathrm{BPA}$ and $\mathrm{Mn}$ (II) for surface sites, which is $\mathrm{pH}$ dependent. ${ }^{33,45}$ Adsorption tests showed that $100 \mu \mathrm{M}$ of $\mathrm{Mn}$ (II) were completely removed at both pH 6.5 and 8 (i.e. dissolved Mn(II) was below the detection limit), while $70 \%$ of the added Mn(II) was removed at $\mathrm{pH} 4$.

To check the affinity of birnessite for $\mathrm{Mn}(\mathrm{II})$ binding, sorption isotherms were determined at three $\mathrm{pH}$ values $(4,6.5$ and 8$)$ under aerobic conditions (Fig. S7). It should be noted that $\mathrm{Mn}$ (II) removal under oxic conditions is expected to be higher than under anoxic conditions, especially at alkaline $\mathrm{pH}$ values, which has been attributed to surface-catalyzed oxidation of $\mathrm{Mn}(\mathrm{II})$ by molecular oxygen. ${ }^{49,50}$ Here, only aerobic conditions were tested, since the aim of these sorption isotherms is to assess the $\mathrm{Mn}(\mathrm{II})$ affinity under oxidizing conditions imposed by the presence of $\mathrm{H}_{2} \mathrm{O}_{2}$. As expected, $\mathrm{Mn}$ (II) binding to $\mathrm{MnO}_{2}$ surfaces increased with $\mathrm{pH}$ increasing. Sorption isotherms showed different shape depending on $\mathrm{pH}$ value across the $\mathrm{Mn}(\mathrm{II})$ concentration range. At $\mathrm{pH} 4$ a typical L-shape with a plateau was observed, while the removal amount continuously increased with $\mathrm{Mn}(\mathrm{II})$ concentration at higher $\mathrm{pH}$ values. This 
high binding of $\mathrm{Mn}(\mathrm{II})$ at high $\mathrm{pH}$ value could cause $\mathrm{Mn}(\mathrm{III})$ enrichment in $\mathrm{MnO}_{2}$ surfaces. ${ }^{49,50}$ Some studies have shown that at high $\mathrm{Mn}(\mathrm{II}) / \mathrm{Mn}(\mathrm{IV})$ ratio and $\mathrm{pH}>7.5$, dissolved $\mathrm{Mn}(\mathrm{II})$ can interact with hexagonal birnessite and then transfer electron to lattice $\mathrm{Mn}(\mathrm{IV})$ producing $\mathrm{Mn}(\mathrm{III}) .{ }^{49,50}$ The buildup of $\mathrm{Mn}(\mathrm{III})$ will induce changes in mineral structure and composition by converting birnessite into lower-valence Mn phases. XRD analysis conducted on samples reacted with $100 \mu \mathrm{M}$ of dissolved $\mathrm{Mn}(\mathrm{II})\left(\mathrm{Mn}(\mathrm{II}) / \mathrm{MnO}_{2}\right.$ molar ratio $\left.=0.3\right)$ showed no notable transformation of $\mathrm{MnO}_{2}$ over the investigated $\mathrm{pH}$ range (Fig. 4). However, titration experiments showed that addition of $100 \mu \mathrm{M}$ of dissolved $\mathrm{Mn}(\mathrm{II})$ dropped down the $\mathrm{AOS}$ of $\mathrm{MnO}_{2}$ from 3.98 to $3.60( \pm 0.05)$ at $\mathrm{pH} 4$ and 6.5 , and $3.50( \pm 0.05)$ at $\mathrm{pH} 8$, suggesting more $\mathrm{Mn}(\mathrm{III})$ or $\mathrm{Mn}(\mathrm{II})$ at the end of reaction with respect to the initial sample. A recent work showed that birnessite transformation into triclinic birnessite and/or $4 \times 4$ tunneled Mn oxide may occur at low $\mathrm{Mn}(\mathrm{II}) / \mathrm{MnO}_{2}$ ratios (0.09 and 0.13 ), while secondary phases such as $\mathrm{MnOOH}$ and $\mathrm{Mn}_{3} \mathrm{O}_{4}$ can be generated at high $\mathrm{Mn}(\mathrm{II}) / \mathrm{MnO}_{2}$ ratios (0.5 and 1). ${ }^{60} \mathrm{In}$ our XRD patterns, broad bands (hump) have appeared between $12^{\circ}$ and $22^{\circ}$ and between $25^{\circ}$ and $35^{\circ}$ in the samples reacted with $\mathrm{Mn}(\mathrm{II})\left(\mathrm{Mn}(\mathrm{II}) / \mathrm{MnO}_{2}\right.$ molar ratio $\left.=0.3\right)$ or $\mathrm{H}_{2} \mathrm{O}_{2}\left(\mathrm{H}_{2} \mathrm{O}_{2} / \mathrm{MnO}_{2}\right.$ molar ratio = 0.6$)$, suggesting changes in the structure or ordering of the birnessite mineral sheets (Fig. 4). We also observed these broad bands in the XRD pattern of synthetic Mn(III)-rich birnessite sample (see Fig. 4). This is consistent with previous studies, which suggested that $\mathrm{Mn}^{\mathrm{III}}$ formation can be made in edge-sharing complexes on $\mathrm{MnO}_{2}$ edge sites or around vacancy sites in octahedral layers of $\mathrm{MnO}_{2} .^{5}$ In addition, a small peak near $20^{\circ}$ only present in the patterns of samples reacted at $\mathrm{pH} 8$ would suggest the presence of feitknechtite $(\beta-\mathrm{MnOOH})$, as previously reported. ${ }^{49}$

\subsection{Synergistic effects of anions and $\mathrm{H}_{2} \mathrm{O}_{2}$ on the oxidative activity of $\mathrm{MnO}_{2}$}

To check whether the suppression of reactivity at environmental relevant concentrations 
of $\mathrm{H}_{2} \mathrm{O}_{2}$ can persist in presence of naturally occurring compounds, the initial rate constants $k$ $\left(\mathrm{h}^{-1}\right)$ of BPA removal were determined at $\mathrm{pH} 6.5$ in presence of silicate, nitrate and phosphate, commonly found in natural systems (Fig. 6). At $0 \mu \mathrm{M}$ of $\mathrm{H}_{2} \mathrm{O}_{2}$, the presence of $100 \mu \mathrm{M}$ of anions did not significantly influence the removal rate of BPA, probably because of weaker interactions of these anionic ligands with $\mathrm{MnO}_{2}$ surfaces under the experimental conditions of this study ( $\mathrm{pH} 6.5,100 \mu \mathrm{M}$ of anion, $345 \mu \mathrm{M}$ of $\mathrm{MnO}_{2}$ ). However, significant decrease in kinetic rate constants was observed in presence of silicate and phosphate when $\mathrm{H}_{2} \mathrm{O}_{2}$ was added in the reaction medium $\left(\mathrm{H}_{2} \mathrm{O}_{2} / \mathrm{MnO}_{2}\right.$ molar ratio between 0.03 and 0.3$)$, while no impact on the reactivity was observed in presence of nitrate (Fig. 6). These results can be explained if the $\mathrm{Mn}(\mathrm{II})$ generated through $\mathrm{H}_{2} \mathrm{O}_{2}$-induced reduction of $\mathrm{MnO}_{2}$ renders the $\mathrm{MnO}_{2}$ surfaces more able to bind anionic ligands, thereby altering the surface reactivity towards BPA.

It was previously reported that unlike nitrate, silicate or phosphate may interact with $\mathrm{MnO}_{2}$ through hydrogen bonding or formation of outer-sphere complexes with surface hydroxyl groups of $\mathrm{MnO}_{2} \cdot{ }^{59-62}$ On the other hand, previous studies reported that the presence of dissolved silicate may decrease the oxidation rate constants of $\mathrm{MnO}_{2}$ toward chlorinated compounds. ${ }^{63,64}$ They have attributed the decrease in $\mathrm{MnO}_{2}$ reactivity to the surface-bound silicate but none of them have provided adsorption data of silicate onto $\mathrm{MnO}_{2}$. In the present work, we showed that silicate or phosphate has a very low affinity to the negatively charged $\mathrm{MnO}_{2}$ surfaces under our experimental conditions, but the presence of $100 \mu \mathrm{M}$ of $\mathrm{Mn}(\mathrm{II})$ significantly enhanced their adsorption amounts onto $\mathrm{MnO}_{2}$ (Fig. S8). This increased adsorption might be due to the changes in both the surface charge of $\mathrm{MnO}_{2}$ and the solution speciation of anionic ligands in the presence of divalent cations such as $\mathrm{Mn}(\mathrm{II})$. Indeed, the ligand speciation may be modified, since different coordination modes of aqueous complexes of phosphate with $\mathrm{Mn}(\mathrm{II})$ ions have been previously reported ${ }^{65}$ However, no precipitation is possible under our experimental conditions due to the low degree of saturation, resulting from 
the very low aqueous concentration of ligand and complete removal of dissolved Mn(II) by adsorption $\left(\log \mathrm{K}_{\mathrm{s}} \mathrm{Mn}(\mathrm{II}) /\right.$ phosphate $\left.=-27.07\right) .{ }^{66}$ Furthermore, Mn(II) binding should lead to a decrease in the negative surface charge, thereby enhancing ability to bind anions through electrostatic interactions. ${ }^{55,58,59}$ Therefore, the $\mathrm{MnO}_{2}$-bound $\mathrm{Mn}$ (II) system could adsorb more effectively anions such as phosphate or silicate through cation bridging, as recently reported for humic acid. ${ }^{55}$ This surface-Mn(II)-ligand ternary complex may act as a barrier to electron transfer between BPA and $\mathrm{Mn}(\mathrm{IV})$ sites, thereby altering reactivity of $\mathrm{MnO}_{2}$ surfaces.

It should be noted that the decomposition of $\mathrm{H}_{2} \mathrm{O}_{2}(200 \mu \mathrm{M})$ was found to be similar in presence or absence of silicate or phosphate $(100 \mu \mathrm{M})$ (Fig. S9). Previous works have investigated the catalytic activity of manganese oxides for hydrogen peroxide decomposition and generation of reactive oxygen species in the context of environmental remediation studies. ${ }^{29-31}$ Despite silicate adsorption on $\mathrm{MnO}_{2}$ surfaces was found negligible, there was an inhibition effect on the $\mathrm{H}_{2} \mathrm{O}_{2}$ decomposition rate over the investigated silicate concentration range ( 0 to $1.5 \mathrm{mM}) .{ }^{30,67}$ Although these works have used different experimental conditions (e.g. much higher concentration of ligands or $\mathrm{H}_{2} \mathrm{O}_{2}$ ), and different $\mathrm{MnO}_{2}$ types, the present findings call for in-depth consideration of the combined/synergistic effects that the cations and anions co-presents in the reaction medium may have on the $\mathrm{MnO}_{2}$ reactivity. Overall, these findings suggest that $\mathrm{Mn}(\mathrm{II})$ generation through $\mathrm{H}_{2} \mathrm{O}_{2}$-mediated reduction may alter both adsorption and redox transformation of environmental compounds.

\section{Conclusions}

Photochemical and dark production of $\mathrm{H}_{2} \mathrm{O}_{2}$ make it ubiquitous not only in oceanic and atmospheric systems but also in the subsurface environment. Here, we have notably demonstrated that environmental levels of hydrogen peroxide can induce reductive dissolution of $\mathrm{MnO}_{2}$ into $\mathrm{Mn}(\mathrm{II})$, thereby affecting the surface reactivity of $\mathrm{MnO}_{2}$. As the $\mathrm{H}_{2} \mathrm{O}_{2}$ 
decomposition is a fast process, the generated dissolved $\mathrm{Mn}$ (II) binds to $\mathrm{MnO}_{2}$ surfaces, altering further interactions with co-existing organic compounds. This may result from competition of organic compound and $\mathrm{Mn}(\mathrm{II})$ to interact with reactive surface sites and/or aqueous complexation with $\mathrm{Mn}(\mathrm{II})$. The presence of silicate or phosphate at concentrations comparable to those encountered in natural waters further decreased the reactivity of $\mathrm{MnO}_{2}$ in presence of $\mathrm{H}_{2} \mathrm{O}_{2}$. Birnessite-bound $\mathrm{Mn}(\mathrm{II})$ adsorbed more effectively anionic ligands such as phosphate or silicate and thus reducing interactions with $\mathrm{BPA}$ at a range of environmentally relevant $\mathrm{pH}$ values. These findings suggest that naturally occurring anions and $\mathrm{H}_{2} \mathrm{O}_{2}$ may have synergetic effects on the reactivity of nanostructured birnessite-type manganese oxide. As manganese oxides can break down high molecular weight humic substances into lower molecular weight organic molecules and/or stabilize dissolved organic carbon, these findings call for in-depth consideration of the impacts of environmental levels of $\mathrm{H}_{2} \mathrm{O}_{2}$ and co-exiting anions on the global carbon cycle. Furthermore, the widespread presence of $\mathrm{H}_{2} \mathrm{O}_{2}$ in surface and ground water systems and associated impacts on the redox-active minerals should be considered in contaminant fate and transport assessment.

\section{Conflicts of interest}

There are no conflicts to declare.

\section{Acknowledgments}

This work was supported by the Institut Universitaire de France, the Region Council of Auvergne Rhône-Alpes and the CNRS. We gratefully acknowledge the Chinese Scholarship Council of PR China for providing financial support for Daqing Jia and Qinzhi Li.

\section{Supplementary Material}


Additional information regarding synthesis and characterization methods, SEM/TEM images, additional data on BPA removal kinetics, fitting procedures and $\mathrm{H}_{2} \mathrm{O}_{2}$ decomposition rate, silicate and phosphate speciation and their adsorption data onto $\mathrm{MnO}_{2}$. 


\section{Reference}

1 J. E. Post, Manganese oxide minerals: Crystal structures and economic and environmental significance, Proc. Natl. Acad. Sci., 1999, 96, 3447-3454.

2 Y. Wang, S. Benkaddour, F. F. Marafatto and J. Peña, Diffusion-and pH-dependent reactivity of layer-type $\mathrm{MnO}_{2}$ : Reactions at particle edges versus vacancy sites, Environ. Sci. Technol., 2018, 52, 3476-3485.

3 N. Birkner and A. Navrotsky, Thermodynamics of manganese oxides: Sodium, potassium, and calcium birnessite and cryptomelane, Proc. Natl. Acad. Sci. U.S.A., 2017, 114, E1046-E1053.

4 S. Wick, J. Peña and A. Voegelin, Thallium sorption onto manganese oxides, Environ. Sci. Technol., 2019, 53, $13168-13178$.

5 B. J. Lafferty, M. Ginder-Vogel, M. Zhu, K. J. Livi and D. L. Sparks, Arsenite oxidation by a poorly crystalline manganese-oxide. 2. Results from X-ray absorption spectroscopy and X-ray diffraction, Environ. Sci. Technol., 2010, 44, 8467-8472.

6 C. K. Remucal and M. Ginder-Vogel, A critical review of the reactivity of manganese oxides with organic contaminants, Environ. Sci. Process. Impacts., 2014, 16, 1247-1266.

7 R. Pokharel, Q. Li, L. Zhou and K. Hanna, Water flow and dissolved Mn(II) alter transformation of pipemidic acid by manganese oxide, Environ. Sci. Technol., 2020, 54, 8051-8060.

8 J. Huang and H. Zhang, Redox reactions of iron and manganese oxides in complex systems, Front. Environ. Sci. Eng., 2020, 14, 76.

9 A. N. Ricko, A. W. Psoras and J. D. Sivey, Reductive transformations of dichloroacetamide safeners: effects of agrochemical co-formulants and iron oxide manganese oxide binary-mineral systems, Environ. Sci.: Processes Impacts., 2020, 22, 2104-2116.

10 M. Villalobos, B. Lanson, A. Manceau, B. Toner and G. Sposito, Structural model for the biogenic Mn oxide produced by Pseudomonas putida, Am. Mineral., 2006, 91, 489-502.

11 S. M. Webb, B. M. Tebo and J. R. Bargar, Structural characterization of biogenic Mn oxides produced in seawater by the marine bacillus sp. strain SG-1, Am. Mineral., 2005, 90, 1342-1357.

12 M. Zhu, M. Ginder-Vogel, S. J. Parikh, X.-H. Feng and D. L. Sparks, Cation effects on the layer structure of biogenic Mn-oxides, Environ. Sci. Technol., 2010, 44, 4465-4471. 
13 M. Villalobos, B. Toner, J. Bargar and G. Sposito, Characterization of the manganese oxide produced by Pseudomonas putida strain MnB1, Geochim. Cosmochim. Acta., 2003, 67, 2649-2662.

14 W. J. Cooper and D. R. Lean, Hydrogen peroxide concentration in a northern lake: Photochemical formation and diel variability, Environ. Sci. Technol., 1989, 23, 1425-1428.

15 R. G. Zika, J. W. Moffett, R. G. Petasne, W. J. Cooper and E. S. Saltzman, Spatial and temporal variations of hydrogen peroxide in gulf of Mexico waters, Geochim. Cosmochim. Acta., 1985, 49, 1173-1184.

16 B. Gonzalez-Flecha and B. Demple, Homeostatic regulation of intracellular hydrogen peroxide concentration in aerobically growing, Escherichia Coli. J. Bacteriol., 1997, 179, 382-388.

17 F. Guillén, A. T. Martinez and M. J. Martínez, Production of hydrogen peroxide by aryl-alcohol oxidase from the ligninolytic fungus Pleurotus Eryngii, Appl. Microbiol. Biotechnol., 1990, 32, 465-469.

18 S. Garg, A. L. Rose and T. D. Waite, Photochemical Production of Superoxide and Hydrogen Peroxide from Natural Organic Matter, Geochim. Cosmochim. Acta., 2011, 75, 4310-4320.

19 J. W. Moffett and O. C. Zajiriou, An investigation of hydrogen peroxide chemistry in surface waters of vineyard sound with $\mathrm{H} 218 \mathrm{O} 2$ and 18O2, Limnol. Oceanogr., 1990, 35, 1221-1229.

20 K. L. Roe, R. J. Schneider, C. M. Hansel and B. M. Voelker, Measurement of dark, particle-generated superoxide and hydrogen peroxide production and decay in the subtropical and temperate North Pacific Ocean, Deep Sea Res. Part I Oceanogr. Res. Pap., 2016, 107, 59-69.

21 W. J. Cooper, J. K. Moegling, R. J. Kieber and J. J. Kiddle, A chemiluminescence method for the analysis of H2O2 in natural waters, Mar. Chem., 2000, 70, 191-200.

22 X. Yuan, P. S. Nico, X. Huang, T. Liu, C. Ulrich, K. H. Williams and J. A. Davis, Production of hydrogen peroxide in groundwater at rifle, Colorado, Environ. Sci. Technol., 2017, 51, 7881-7891.

23 P. Liao, K. Yu, Y. Lu, P. Wang, Y. Liang and Z. Shi, Extensive dark production of hydroxyl radicals from oxygenation of polluted river sediments, Chem. Eng. J., 2019, 368, 700-709. 
24 E. Kim, Y. Liu, C. J. Baker, R. Owens, S. Xiao, W. E. Bentley and G. F. Payne, Redox-cycling and H2O2 generation by fabricated catecholic films in the absence of enzymes, Biomacromolecules., 2011, 12, $880-888$.

25 S. E. Page, G. W. Kling, M. Sander, K. H. Harrold, J. R. Logan, K. McNeill and R. M. Cory, Dark Formation of hydroxyl radical in arctic soil and surface waters, Environ. Sci. Technol., 2013, 47, 12860 12867.

26 J. D. Begg, M. Zavarin and A. B. Kersting, Plutonium desorption from mineral surfaces at environmental concentrations of hydrogen peroxide, Environ. Sci. Technol., 2014, 48, 6201-6210.

27 H.-P. Li, C. M. Yeager, R. Brinkmeyer, S. Zhang, Y.-F. Ho, C. Xu, W. L. Jones, K. A. Schwehr, S. Otosaka and K. A. Roberts, Bacterial production of organic acids enhances H2O2-dependent iodide oxidation, Environ. Sci. Technol., 2012, 46, 4837-4844.

28 M. Amme, W. Bors, C. Michel, K. Stettmaier, G. Rasmussen and M. Betti, Effects of Fe(II) and hydrogen peroxide interaction upon dissolving UO2 under geologic repository conditions, Environ. Sci. Technol., 2005, 39, 221-229.

29 R. J. Watts, J. Sarasa, F. J. Loge and A. L. Teel, Oxidative and reductive pathways in manganese-catalyzed Fenton's reactions, J. Environ. Eng., 2005, 131, 158-164.

30 A. L.-T. Pham, F. M. Doyle and D. L. Sedlak, Inhibitory effect of dissolved silica on $\mathrm{H}_{2} \mathrm{O}_{2}$ decomposition by iron(III) and manganese(IV) oxides: Implications for $\mathrm{H}_{2} \mathrm{O}_{2}$-based in situ chemical oxidation, Environ. Sci. Technol., 2012, 46, 1055-1062.

31 M. Kamagate, M. Pasturel, M. Brigante and K. Hanna, Mineralization enhancement of pharmaceutical contaminants by radical-based oxidation promoted by oxide-bound metal ions, Environ. Sci. Technol., 2019, 54, 476-485.

32 S. Balgooyen, P. J. Alaimo, C. K. Remucal and M. Ginder-Vogel, Structural transformation of MnO2 during the oxidation of bisphenol A, Environ. Sci. Technol., 2017, 51, 6053-6062.

33 K. Lin, W. Liu and J. Gan, Oxidative removal of bisphenol A by manganese dioxide: efficacy, products, and pathways, Environ. Sci. Technol., 2009, 43, 3860-3864. 
34 J. Huang, S. Zhong, Y. Dai, C.-C. Liu and H. Zhang, Effect of MnO2 phase structure on the oxidative reactivity toward bisphenol A degradation, Environ. Sci. Technol., 2018, 52, 11309-11318.

35 S. Balgooyen, G. Campagnola, C. K. Remucal and M. Ginder-Vogel, Impact of bisphenol A influent concentration and reaction time on $\mathrm{MnO} 2$ transformation in a stirred flow reactor, Environ. Sci. Process. Impacts., 2019, 21, 19-27.

36 R. M. McKenzie, The synthesis of birnessite, cryptomelane, and some other oxides and hydroxides of manganese, Mineral. Mag., 1971, 38, 493-502.

37 Q. Sun, P. X. Cui, T. T. Fan, S. Wu, M. Zhu, M. E. Alves, D. M. Zhou and Y. J. Wang, Effects of Fe (II) on Cd (II) immobilization by Mn (III)-rich $\delta$-MnO2, Chem. Eng. J., 2018, 353, 167-175.

38 A. A. Simanova, K. D. Kwon, S. E. Bone, J. R. Bargar, K. Refson, G. Sposito and J. Peña, Probing the sorption reactivity of the edge surfaces in birnessite nanoparticles using nickel (II), Geochim. Cosmochim. Acta., 2015, 164, 191-204.

39 Y. Wu, M. Passananti, M. Brigante, W. Dong and G. Mailhot, Fe (III)-EDDS Complex in Fenton and photo-Fenton processes: From the radical formation to the degradation of a target compound, Environ. Sci. Pollut. Res., 2014, 21, 12154-12162.

40 T. Charbouillot, M. Brigante, G. Mailhot, P. R. Maddigapu, C. Minero and D. Vione, Performance and selectivity of the terephthalic acid probe for $\mathrm{OH}$ as a function of temperature, $\mathrm{pH}$ and composition of atmospherically relevant aqueous media, J. Photochem. Photobiol. A., 2011, 222, 70-76,

$41 \mathrm{~J}$. Mullin and J. Riley, The colorimetric determination of silicate with special reference to sea and natural waters, Anal. Chim. Acta., 1955, 12, 162-176.

42 V. Ruiz-Calero and M. T. Galceran, Ion chromatographic separations of phosphorus species: a review, Talanta., 2005, 66, 376-410.

43 Q. Li, R. Pokharel, L. Zhou, M. Pasturel and K. Hanna, Coupled effects of Mn(II), pH and anionic ligands on the reactivity of nanostructured birnessite, Environ. Sci. Nano., 2020, 7, 4022-4031. 
44 J. Im, C. W. Prevatte, S. R. Campagna and F. E. Löffler, Identification of 4-hydroxycumyl alcohol as the Major MnO2-mediated bisphenol A transformation product and evaluation of its environmental fate, Environ. Sci. Technol., 2015, 49, 6214-6221.

45 H. Zhang, W. R. Chen and C. H. Huang, Kinetic modeling of oxidation of antibacterial agents by manganese oxide, Environ. Sci. Technol., 2008, 42, 5548-5554.

46 W. Stumm and J. J. Morgan, Aquatic chemistry: Chemical equilibria and rates in natural waters, John Wiley \& Sons., 2012.

47 S. Baral, C. Lume-pereira, E. Janata and A. Henglein, Chemistry of colloidal manganese dioxide. Part 2. Reaction with O2-and H2O2 (Pulse radiolysis and stop flow studies), J. Phys. Chem., 1985, 89, 57795783.

48 D. B. Broughton and R. L.Wentworth, Mechanism of decomposition of hydrogen peroxide solutions with manganese dioxide. I, J. Am. Chem. Soc., 1947, 69, 741-744.

49 J. P. Lefkowitz, A. A. Rouff and E. J. Elzinga, Influence of $\mathrm{pH}$ on the reductive transformation of birnessite by aqueous Mn(II), Environ. Sci. Technol., 2013, 47, 10364-10371.

50 E. J. Elzinga, Reductive transformation of birnessite by aqueous Mn(II), Environ. Sci. Technol., 2011, 45, 6366-6372.

51 Q. Wang, P. Yang and M. Zhu. Structural Transformation of Birnessite by Fulvic Acid under Anoxic Conditions, Environ. Sci. Technol., 2018, 52, 1844-1853.

$52 \mathrm{H}$. Yin, Y. Zhou, J. Xu, S. Ai, L. Cui and L. Zhu, Amperometric biosensor based on tyrosinase immobilized onto multiwalled carbon nanotubes-cobalt phthalocyanine-silk fibroin film and its application to determine bisphenol A, Anal. Chim. Acta., 2010, 659, 144-150.

53 H. Yin, Y. Zhou, L. Cui, X. Liu, S. Ai and L. Zhu, Electrochemical oxidation behavior of bisphenol A at surfactant/layered double hydroxide modified glassy carbon electrode and its determination, J. Solid State Electrochem., 2011, 15, 167-173. 
54 Ş. U. Karabiberoğlu, Sensitive voltammetric determination of bisphenol A based on a glassy carbon electrode modified with copper oxide - zinc oxide decorated on graphene oxide, Electroanalysis., 2019, 31, 91-102.

55 H. Chenga, T. Yang, J. Jiang, X. Lu, P. Wanga and J. Ma, Mn2+ effect on manganese oxides (MnOx) nanoparticles aggregation in solution: Chemical adsorption and cation bridging, Environ. Pollut., 2020, 267, 115561 .

56 H. Zhao, M. Zhu, W. Li, E. J. Elzinga, M. Villalobos, F. Liu, J. Zhang, X. Feng and D. L. Sparks, Redox Reactions between Mn (II) and Hexagonal Birnessite Change its Layer Symmetry, Environ. Sci. Technol., 2016, 50, 1750-1758.

57 S. M. Webb, G. J. Dick, J. R. Bargar and B. M. Tebo, Evidence for the presence of Mn(III) intermediates in the bacterial oxidation of Mn(II), Proc. Natl. Acad. Sci., 2005, 102, 5558-5563.

58 T. Takamatsu, M. Kawashima and M. Koyama, The role of Mn(II)-rich hydrous manganese oxide in the accumulation of arsenic in lake sediments, Water. Res., 1985, 19, 1029-1032.

59 W. Yao and F. J. Millero, Adsorption of phosphate on manganese dioxide in seawater, Environ. Sci. Technol., 1996, 30, 536-541.

60 P. Yang, K. Wen, K. A. Beyer, W. Xu, Q. Wang, D. Ma, J.Wu and M. Zhu, Inhibition of Oxyanions on Redox-driven Transformation of Layered Manganese Oxides, Environ. Sci. Technol., 2021, 55, 34193429.

61 S. Mustafa, M. I. Zaman and S. Khan, pH effect on phosphate sorption by crystalline MnO2, J. Colloid Interface Sci., 2006, 301, 370-375.

62 L. S. Balistrieri and T. T. Chao, Adsorption of selenium by amorphous iron oxyhydroxide and manganese dioxide, Geochim. Cosmochim. Acta., 1990, 54, 739-751.

$63 \mathrm{~S}$. Taujale and $\mathrm{H}$. Zhang, Impact of interactions between metal oxides to oxidative reactivity of manganese dioxide, Environ. Sci. Technol., 2012, 46, 2764-2771. 
64 M. Yu, X. He, B. Xi, Y. Xiong, Z. Wang, D. Sheng, L. Zhu and X. Mao, Dissolved Silicate Enhances the Oxidation of Chlorophenols by Permanganate: Important Role of Silicate-Stabilized MnO2 Colloids, Environ. Sci. Technol., 2020, 54, 10279-10288.

65 C. K. Sharma, C. C. Chusuei, R. Clérac, T. Möller, K. R. Dunbar and A. Clearfield, Magnetic property studies of manganese-phosphate complexes, Inorg. Chem., 2003, 42, 8300-8308.

66 G. Friedl, B. Wehrli and A. Manceau, Solid phases in the cycling of manganese in eutrophic lakes: New insights from EXAFS spectroscopy, Geochim. Cosmochim. Acta., 1997, 61, 275-290.

$67 \mathrm{~K}$. Hanna, Comment on "Inhibitory effect of dissolved silica on $\mathrm{H}_{2} \mathrm{O}_{2}$ decomposition by iron (III) and manganese (IV) oxides: implications for $\mathrm{H}_{2} \mathrm{O}_{2}$-based in situ chemical oxidation", Environ. Sci. Technol., 2012, 46, 3591-3592. 


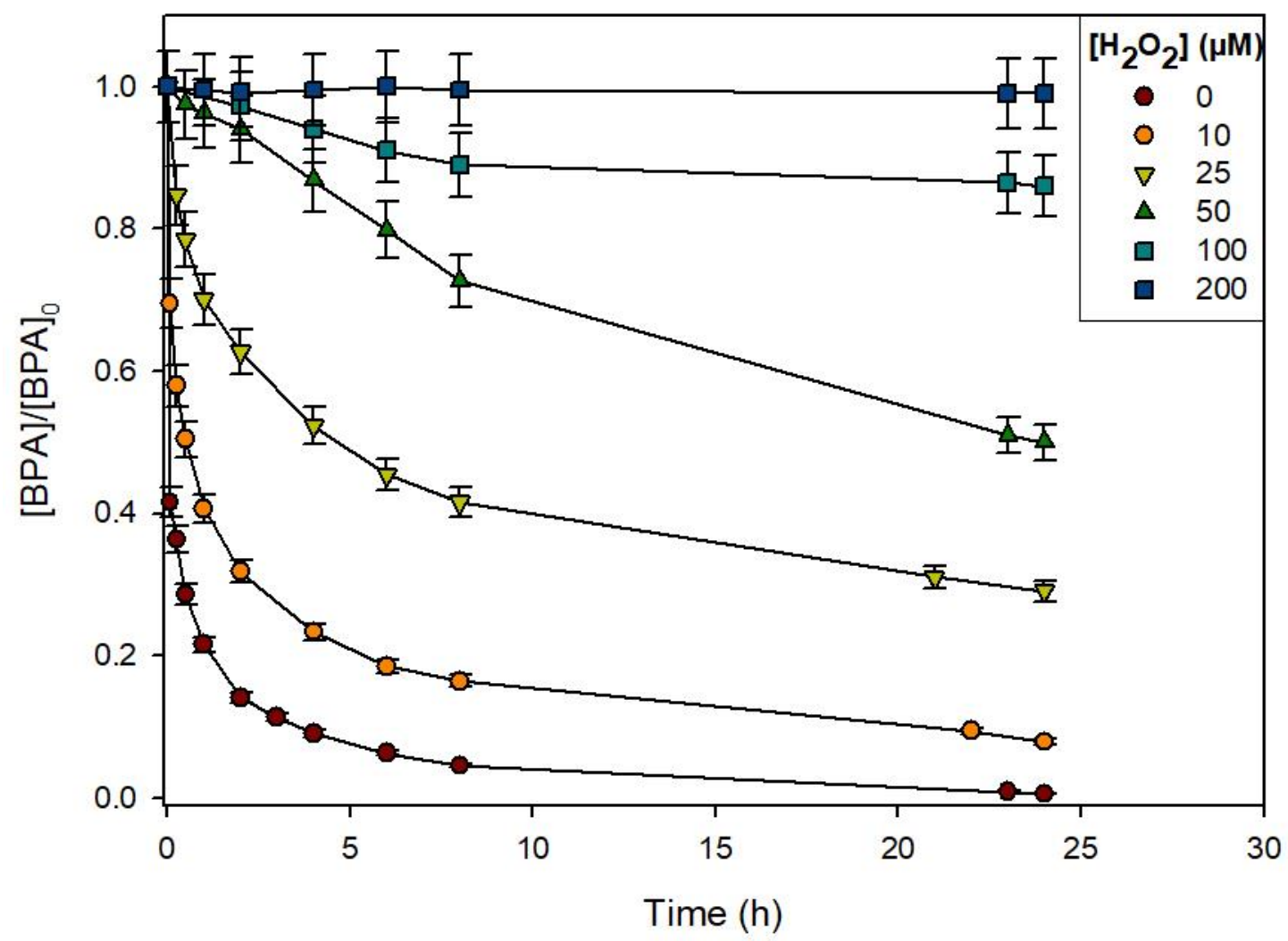

Figure 1. Effect of $\mathrm{H}_{2} \mathrm{O}_{2}$ concentration on the BPA removal at $\mathrm{pH} 6.5$ at room temperature. Experimental conditions: $[\mathrm{AB}]=345 \mu \mathrm{M},[\mathrm{BPA}]=25 \mu \mathrm{M} . \mathrm{H}_{2} \mathrm{O}_{2} / \mathrm{MnO}_{2}$ ratio $=0-0.6$. The relative experimental error lied at $5 \%$ for BPA. 


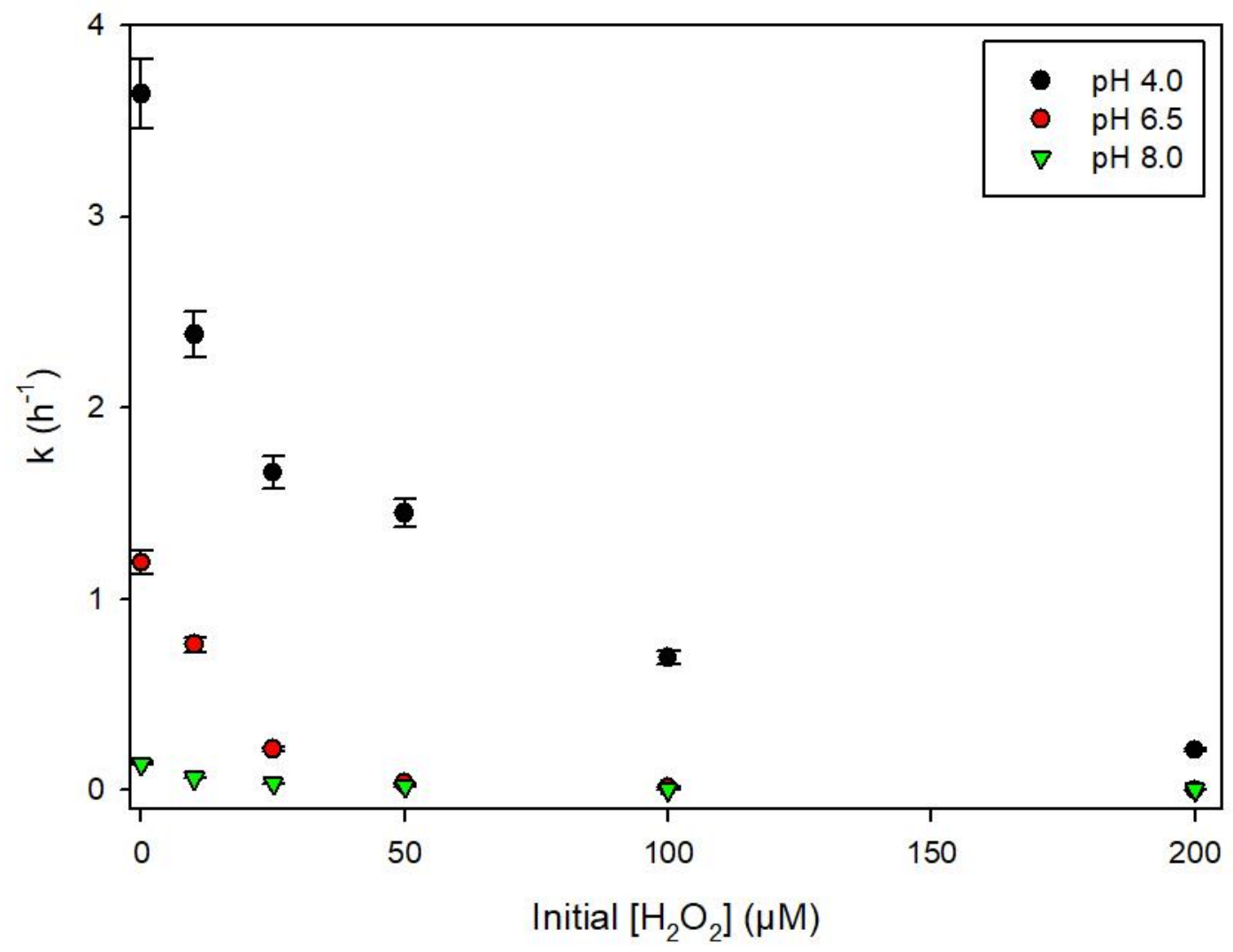

Figure 2. Removal rate constants $\left(\mathrm{h}^{-1}\right)$ of $\mathrm{BPA}$ as a function of $\mathrm{H}_{2} \mathrm{O}_{2}$ dose at three $\mathrm{pH}$ values $(4$, 6.5 and 8). Experimental conditions: $[\mathrm{AB}]=345 \mu \mathrm{M},[\mathrm{BPA}]=25 \mu \mathrm{M},\left[\mathrm{H}_{2} \mathrm{O}_{2}\right]=0-200 \mu \mathrm{M}$. $\mathrm{H}_{2} \mathrm{O}_{2} / \mathrm{MnO}_{2}$ ratio $=0-0.6$, room temperature. The relative experimental error lied at $5 \%$. 

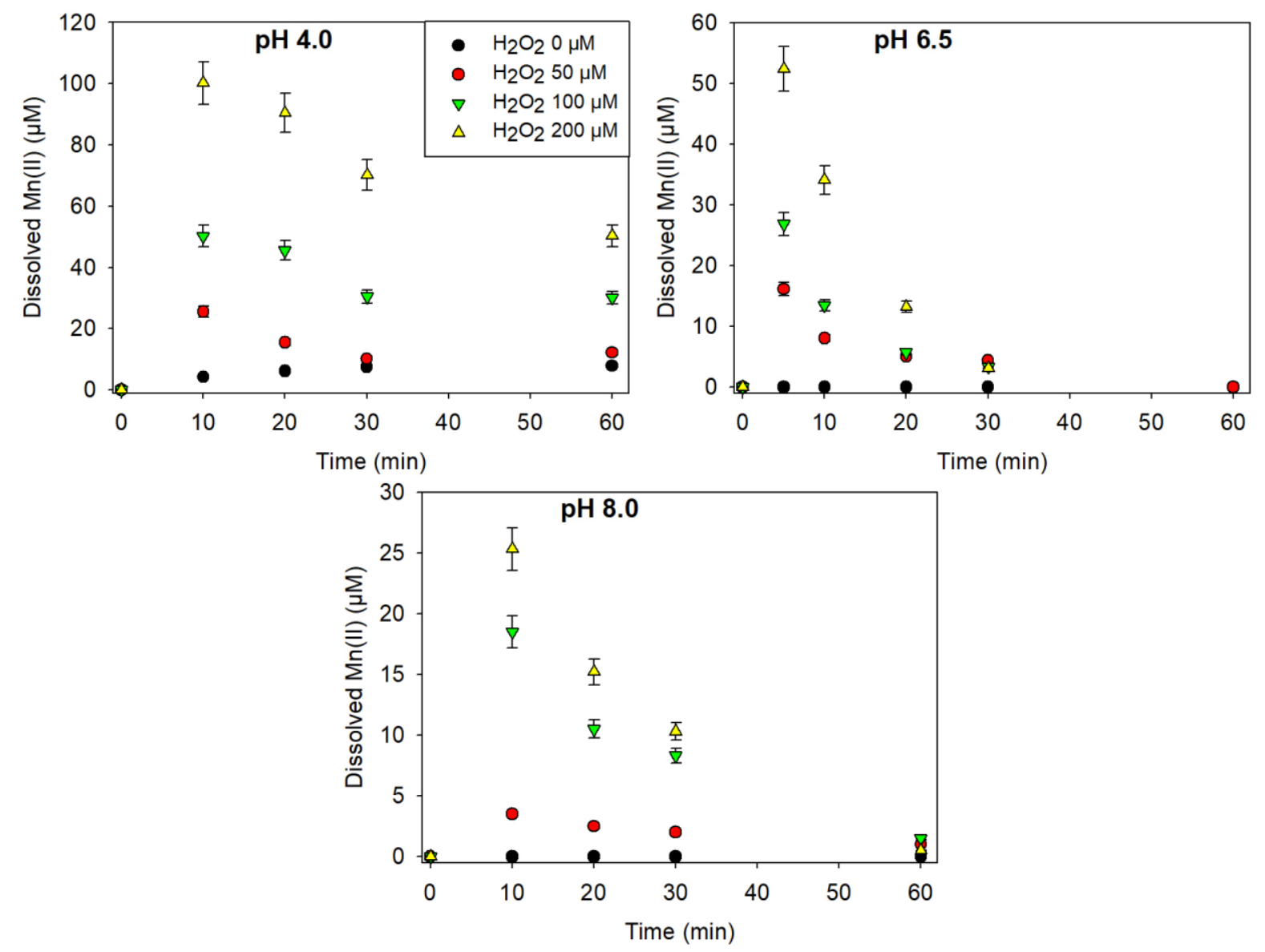

Figure 3. $\mathrm{Mn}(\mathrm{II})$ formation under different $\mathrm{H}_{2} \mathrm{O}_{2}$ concentrations and $\mathrm{pH} 4.0,6.5$ and 8.0. Experimental conditions: $[\mathrm{AB}]=345 \mu \mathrm{M}$ and $[\mathrm{BPA}]=25 \mu \mathrm{M} . \mathrm{H}_{2} \mathrm{O}_{2} / \mathrm{MnO}_{2}$ ratio $=0-0.6$, room temperature. The relative experimental error lied at $7 \%$ for $\mathrm{Mn}(\mathrm{II})$. 


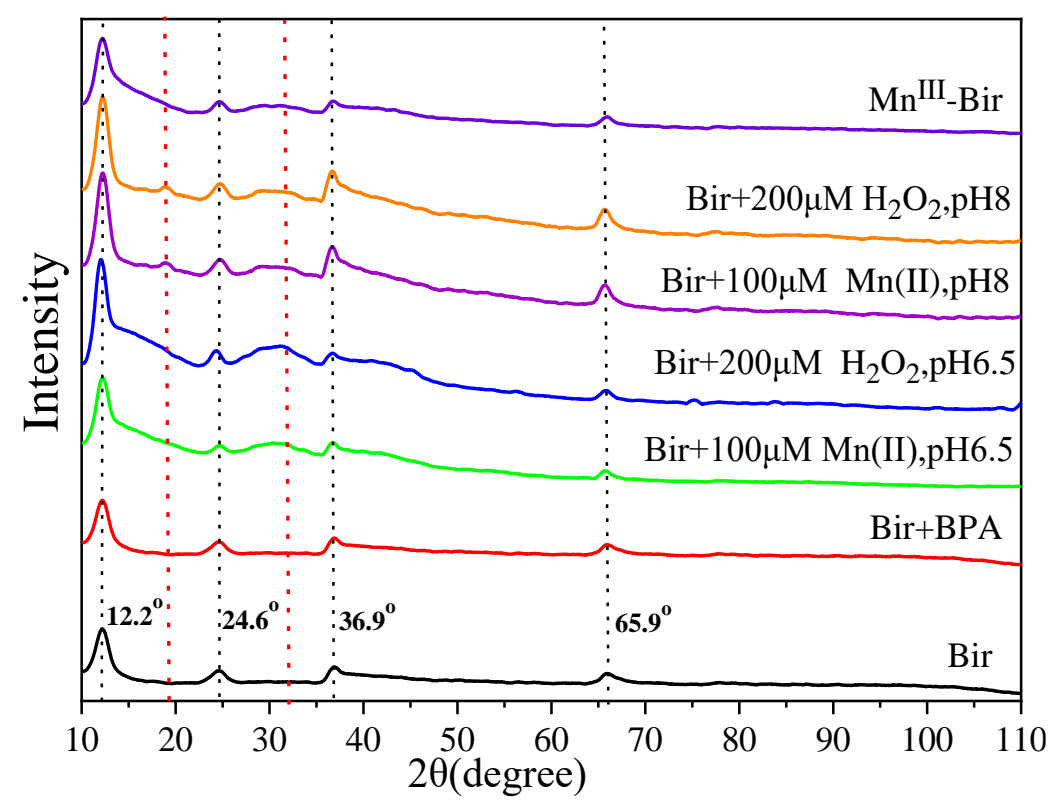

Figure 4. XRD patterns of birnessite before and after reaction in the presence of $\mathrm{H}_{2} \mathrm{O}_{2}$ or $\mathrm{Mn}(\mathrm{II})$ (two $\mathrm{pH}$ values, $24 \mathrm{~h}$ of reaction time), and of $\mathrm{Mn}$ (III) rich Birnessite. The black dashed lines indicate the peaks of acid birnessite, while the red dashed lines indicate broad bands appeared in reacted samples. Experimental conditions: $[\mathrm{AB}]=345 \mu \mathrm{M}$ and $[\mathrm{BPA}]=25 \mu \mathrm{M} . \mathrm{H}_{2} \mathrm{O}_{2} / \mathrm{MnO}_{2}$ ratio $=0.6 . \mathrm{Mn}(\mathrm{II}) / \mathrm{MnO}_{2}$ ratio $=0.3$. The solid was characterized using $\mathrm{X}$-ray powder diffraction (XRD) with a Bruker AXS D8 Advance diffractometer $(\theta-2 \theta$ Bragg-Brentano geometry) using monochromated $\mathrm{Cu} \mathrm{K} \alpha_{1}(1.54 \AA)$ radiation. 


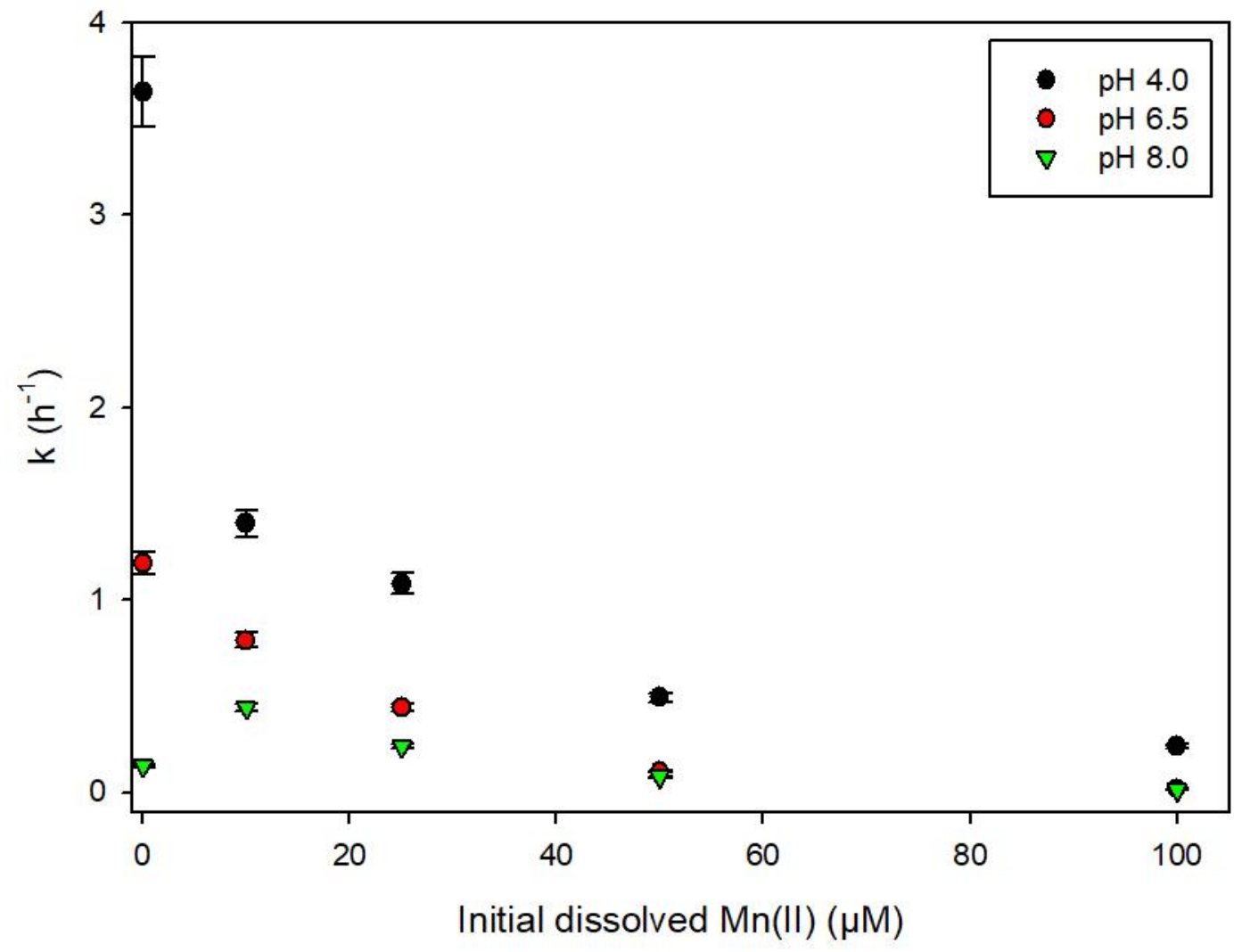

Figure 5. Removal rate constants $\left(\mathrm{h}^{-1}\right)$ of $\mathrm{BPA}$ as a function of $\mathrm{Mn}(\mathrm{II})$ concentration at three $\mathrm{pH}$ values (4, 6.5 and 8$)$. Experimental conditions: $[\mathrm{AB}]=345 \mu \mathrm{M},[\mathrm{BPA}]=25 \mu \mathrm{M},[\mathrm{Mn}(\mathrm{II})]=0$ - $100 \mu \mathrm{M}$, room temperature. The relative experimental error lied at $5 \%$. 


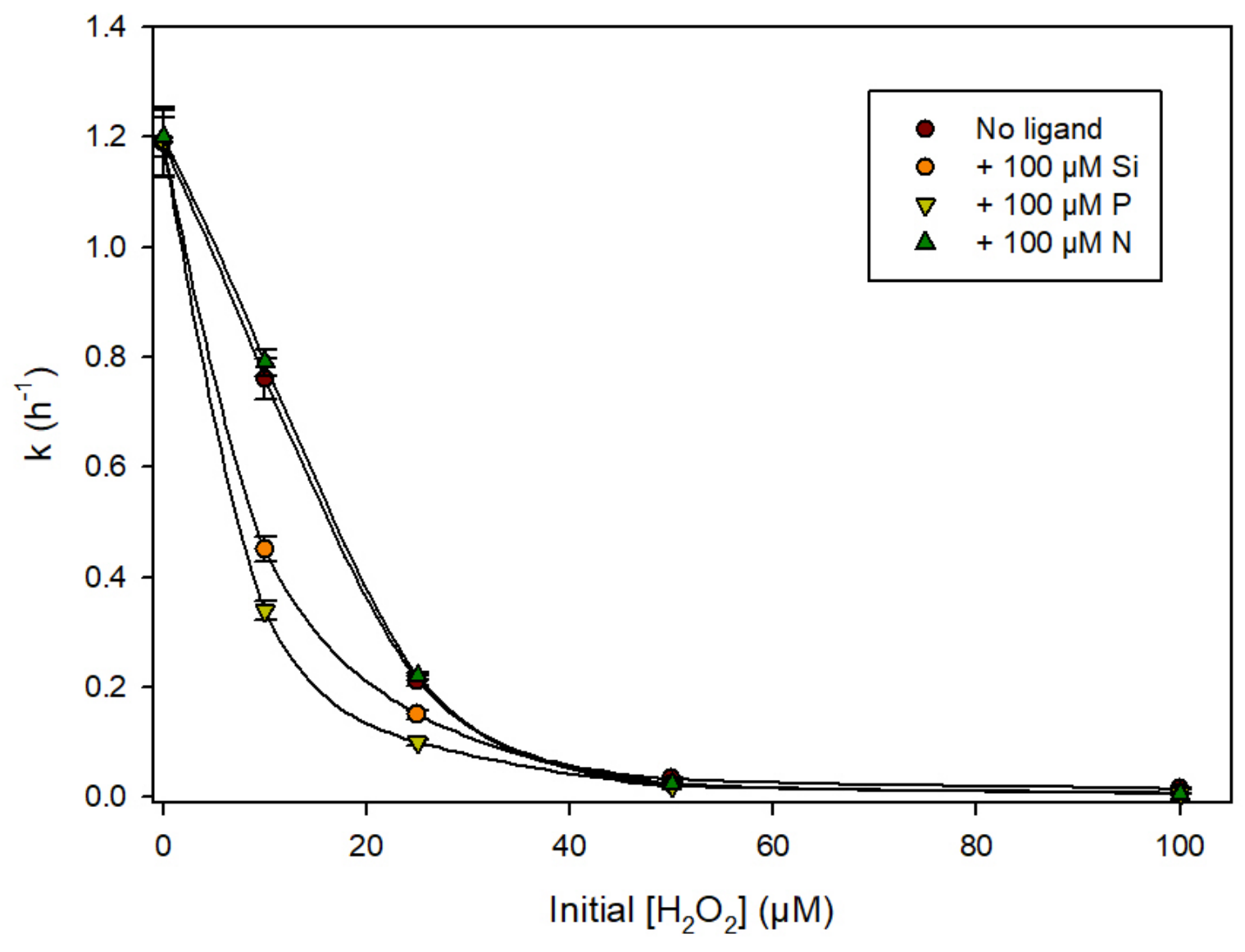

Figure 6. Removal rate constants $\left(\mathrm{h}^{-1}\right)$ of BPA as a function of $\mathrm{H}_{2} \mathrm{O}_{2}$ dose in absence or presence of silicate $(\mathrm{Si})$, nitrate $(\mathrm{N})$ or phosphate $(\mathrm{P})$ : Experimental conditions: $\mathrm{pH} 6.5,[\mathrm{AB}]=345 \mu \mathrm{M}$, $[\mathrm{BPA}]=25 \mu \mathrm{M}$; $\left[\mathrm{Na}_{2} \mathrm{SiO}_{3}\right]=100 \mu \mathrm{M} ;\left[\mathrm{NaNO}_{3}\right]=100 \mu \mathrm{M} ;\left[\mathrm{NaH}_{2} \mathrm{PO}_{4}\right]=100 \mu \mathrm{M} . \mathrm{H}_{2} \mathrm{O}_{2} / \mathrm{MnO}_{2}$ ratio $=0-0.3$, room temperature. The relative experimental error lied at $5 \%$. 